\title{
Studies of heavy metal contents and microbial composition of rhizosphere of Panicum maximum within and around auto mechanic workshop in Benin City
}

\section{OMOREGBEE OSAZUWA ${ }^{1 *}$, IKHAJIAGBE BECKLEY ${ }^{2}$, UDINYIWE COLLINS OSAYAMEN ${ }^{1}$}

\author{
${ }^{I}$ Dept. Science Laboratory Technology, University of Benin, Benin City \\ ${ }^{2}$ Dept. of Plant Biol. and Biotechnology, University of Benin, Benin City \\ *Corresponding author: Mr. Osazuwa Omoregbee, Dept. Science Laboratory Technology, University of Benin, Benin City. \\ Email: crestedsas_4good@yahoo.com
}

\begin{abstract}
This study investigated the heavy metal content and microbial composition of rhizosphere of Panicum maximum obtained from some auto mechanic workshops in Benin City, Nigeria. The grass was uprooted and soil sample was taken from its rhizosphere. The sample were labeled appropriately and immediately transported into a polythene bag covered with aluminium foil papers. It was then taken to the laboratory for heavy metals and microbial assay. The results showed that average plant density of Panicum maximum per $100 \mathrm{~m}^{2}$ of sampled subplots in the mechanic workshops was 8.50 in Ikpoba-Okha and 9.00 in Oredo, compared to 27.50 in the control. Fe content of rhizospheric soil in Ikpoba-Okha was $1527.6 \mathrm{mg} / \mathrm{kg}$ and $1653.1 \mathrm{mg} / \mathrm{kg}$ in Egor, compared to $1002.2 \mathrm{mg} / \mathrm{kg}$ in the control. Mean heavy metal content of rhizospheric soils was $11.71 \mathrm{mg} / \mathrm{kg}$ of $\mathrm{Mn}, 0.031 \mathrm{mg} / \mathrm{kg}$ of Pb, and $9.98 \mathrm{mg} / \mathrm{kg}$ of Cr. Total hydrocarbon content ranged from $1445.0-2314.2 \mathrm{mg} / \mathrm{kg}$ in the oil-polluted soils, compared to $851.5 \mathrm{mg} / \mathrm{kg}$ in the control soil. Total bacterial count of the rhizospheric soils collected from Ikpoba-Okha sampling site was $5.40 \times 10^{6} \mathrm{cfu} / \mathrm{g} ; 5.30 \times 10^{6} \mathrm{cfu} / \mathrm{g}$ in Ovia NE, and $4.90 \times 10^{6}$ cfu/g in Egor, compared to $0.39 \times 10^{6} \mathrm{cfu} / \mathrm{g}$ in the control. Comparatively, bacterial counts outnumbered fungal counts. Percentage hydrocarbon degrading fungi was $133.3 \%$ in samples collected from Oredo, compared to 31.82 in the control. The most prevalent fungal species was Aspergillus niger, whereas Micrococcus varians was the most prevalent bacterial species. (C) JASEM
\end{abstract}

\section{http://dx.doi.org/10.4314/jasem.v19i2.14}

\section{INTRODUCTION}

The problem associated with heavy metal contamination of soils, particularly those of auto mechanic workshops, where there is also the problem of hydrocarbon contamination to grapple with, leaves much to be told. Pollution is one of the most important problems around the world today in which thousands of millions of world inhabitants suffer health problems related to industry and atmospheric pollutants. In recent years, significant attention being paid to the problems of environmental contamination by chemical pollutants including heavy metals (Adie and Osibanjo, 2009).

Auto mechanic workshop is a major source of environmental pollution in Nigeria. Due to the epileptic nature of public power supply in Nigeria, the use of private electricity generating sets, in recent times, have increased the need for engine lubricants (Anoliefo and Edegbai, 2001). The disposal of this waste oil into gutters, open vacant plots and farms is a common practice mostly done by auto mechanics and allied artisans. Waste engine oil pollution is responsible for several environmental problems, risks to human health and plants, including decreased soil microbial activity and fertility (Anoliefo et al., 2006).

There are relatively large amounts of hydrocarbons in the spent engine oil including the highly toxic polycyclic aromatic hydrocarbon (PAH) (Wei et al., 2005). Waste engine oil in soil creates unsatisfactory conditions for plant growth ranging from heavy metal toxicity to insufficiency in aeration of the soil (Anoliefo et al., 2006). Odjegba and Sadiq (2002) reported that pollution from waste engine oil (WEO) is another important environmental problem and is more widespread than crude oil pollution. The WEO as a petroleum product contains potentially hazardous chemicals, particularly the polycyclic aromatic hydrocarbons (PAHs), heavy metals and chemicals additives including amines, phenol, benzenes (Meinz, 1999). Ikhajiagbe and Anoliefo (2011) reported that WEO pollution becomes widespread when they are carried by run-off during rainfall to nearby farms. The concentration of PAHs in lubricating oil increases with time of usage and those with two and three rings accumulate rapidly in used lubricating oil to very high levels (Vwioko and Fashemi, 2005). Although the chemicals found in oil contaminated soil do not contain hetero-atoms or substituents 
(Fetzer, 2000), they can cause a reduction in the level of available plant nutrients and a rise to a toxic level of elements such as manganese.

This problem seems unending especially with the dawn of global industrialization and so is considered as a major risk for human communities throughout the world. It is only necessary that these contaminants be removed to minimize the entry of these potentially toxics into the food chain (Mohsen et al., 2011).

An important contribution to the degradation of organic pollutants is ascribed to the microbes present in the rhizosphere of plants (Anderson et al., 1993; Schwab and Banks, 1994). Hence recently, the combination of microbes and plant (rhizoremediation) in the remediation of pollutants has become a general practice in the field treatment of petroleum contaminated soil (Gerhardta et al., 2009). Most of these are majorly found in the welldeveloped rooting systems of most grass species. One of such species is Panicum maximum.

Panicum maximum (guinea grass) is a clump-forming perennial which grows best in warm frost-free areas. Guinea grass can withstood continuous heavy grazing with stocking rates of 2.5 cattle/ha for long periods under heavy annual rainfall and it performs better under rotational grazing. It is the aim of this paper to present the heavy metal content of Panicum maximum, and microbial composition of the polluted soil and evaluate the impact of heavy metal on soil degradable organism.

\section{MATERIALS AND METHODS}

Study Area: This study was carried out in four Local Government Areas of the State; Ikpoba-Okha, Ovia North east, Egor and Oredo within Benin Metropolis, the administrative headquarters of Edo state of Nigeria. Benin City is located within longitude $5^{\circ} 24^{\prime}$ and $6^{0} 35^{\prime} \mathrm{E}$ and latitude $5^{\circ} 36^{\prime}$ and $5^{\circ} 47^{\prime}$ of the equator. The area has a hot humid climate with two distinct seasons - the wet season (May to November) and dry season (November to April). Mean annual rainfall is about $2,500 \mathrm{~mm}$ which displays a bi-modal pattern characteristic of the Southern part of West Africa. There is a short dry period in August associated with the passage of inter-tropical discontinuity. The rainfall maxima occur in July and September. The mean monthly temperature is about $31^{0} \mathrm{C}$ with little variations throughout the year. Fagbani and Fapohunda (1986) put the land as nearly level with long interfluves slope that are inclined very gently towards Ikpoba Valley.
Experimental Procedure: Selection of auto mechanic workshops for the study was based on the presence of waste engine oil spills on the ground due to the activities of mechanics within the City. For collection of soil and plant samples, an auto mechanic workshop at Evbareke represented the collection from Egor local Government Area. Others included auto mechanic workshop at Aduwawa for Ikpoba Okha local Government Area, the Igun auto mechanic workshop for Oredo Local Government Area, and the Oluku auto mechanic workshop for Ovia North East Local Government Area.

Collection of Samples: Panicum maximum grass within some auto mechanic workshop in Benin City was uprooted and soil sample was taken from its rhizosphere. The sample were labelled appropriately and immediately transported into a polythene bag covered with aluminum foil papers. It was then taken to the laboratory for heavy metals and microbial assay. Soil collection was usually in the morning (between 6-7am). Soils were analysed for heavy metal composition using atomic spectrometry (AOAC, 2005), whereas isolation and characterization of bacterial, fungal and actinomycete oil degraders was carried out using the methods of Cowan and Steel (1974), Sabba (1995), Cheesebrough, (1998) and Taiwo and Oso (2004).

\section{RESULTS AND DISCUSSION}

The result for the average plant density per $100 \mathrm{~m}^{2}$ of Panicum maximum within subplots $(10 \mathrm{~m} \times 10 \mathrm{~m})$ in the mechanic workshops (Table 1) showed that average plant density for the control was 27.50 per $100 \mathrm{~m}^{2}$, compared to plant density for Ikpoba-Okha (8.50) and Oredo (9.00). It was clear that the control plants had the most favorable soil for growth and development.

Heavy metal contents of rhizopheric soils for IkpobaOkha showed a value of $1527.6 \mathrm{mg} / \mathrm{kg}$ for $\mathrm{Fe}$; $\mathrm{Fe}$ concentration in Ovia NE was however 1124.5 $\mathrm{mg} / \mathrm{kg}$, and $1653.1 \mathrm{mg} / \mathrm{kg}$ in Egor. There were traces of $\mathrm{Pb}$ in all the samples. The concentration of $\mathrm{V}$ in rhizospheric soil of Panicum maximum was insignificant for all studied districts including the control (Table 2). Hazard quotient to show soil phytotoxicity of heavy metal contents of rhizosphere soil have been presented on Table 3. The hazard quotient for metals assayed was less then unity, except for $\mathrm{Fe}$; an indication that metal levels within the rhizosphere was not high enough to cause phytotoxic effects on the test plant. Hazard quotient to show also toxicity of heavy metal contents to microbial activity and processes was similarly less than unity (Table 4). 
The results for the microbial species composition within the rhizosphere have been presented on Table 3. Total bacterial count was $0.39 \times 10^{6} \mathrm{cfu} / \mathrm{g}$ in the control. However, bacterial count within the rhizospheric soils collected from Ikpoba-Okha sampling site was $5.40 \times 10^{6} \mathrm{cfu} / \mathrm{g} ; 5.30 \times 10^{6} \mathrm{cfu} / \mathrm{g}$ in Ovia NE, and $4.90 \times 10^{6} \mathrm{cfu} / \mathrm{g}$ in Egor. Total hydrocarbon-degrading bacterial count ranged from $2.10-2.70 \times 10^{6} \mathrm{cfu} / \mathrm{g}$ in the oil-polluted zones, compared to $0.03 \times 10^{6} \mathrm{cfu} / \mathrm{g}$ in the control. Total fungal count ranged from $0.9-2.0 \times 10^{6} \mathrm{cfu} / \mathrm{g}$ in the oil-polluted sampling areas, compared to $2.2 \times 10^{6}$ $\mathrm{cfu} / \mathrm{g}$ in the control. Comparatively, bacterial counts outnumbered fungal counts. Percentage hydrocarbon degrading fungi was $133.3 \%$ in samples collected from Oredo, compared to 31.82 in the control (Table $3)$.

The Table 4 shows the bacteria and fungi isolated from this experiment. From the bacteria isolated, only Bacillus subtilis was present in Ikpoba-Okha, Oredo, Ovia NE and not present in Egor, all the rest bacteria isolate (Micrococcus luteus, Micrococcus varians, Pseudomonas putida, Achromobacter sp, Bacillus pumilis, Clostridium sp and Serratia marascens) were not present in all the samples. While the fungi isolated (Penicillium sp) were present in IkpobaOkha and Oredo, Aspergillus niger and Fusarium solani also were present in Oredo, Egor and Ovia NE, the rest isolate (Aspergillus flavus, Geotrichum $s p$, Rhizopus sp, Trichoderma $s p$ ) were absent in all samples repectively

Table 1: Average plant density (No. of plants per $100 \mathrm{~m}^{2}$ ) of Panicum maximum within subplots $(10 \mathrm{~m} \times 10 \mathrm{~m})$ in the mechanic workshops.

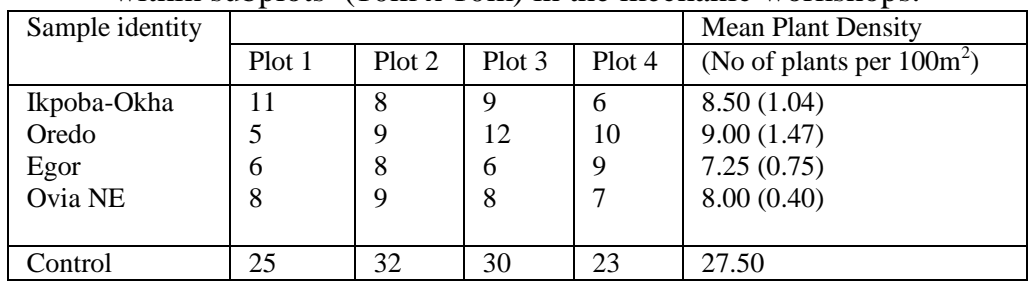

Values in parenthesis are standard errors from the mean

Table 2: Heavy metals of rhizopheric soils of Panicum maximum in some auto mechanic workshops in Benin City

\begin{tabular}{|l|l|l|l|l|l|l|l|l|l|l|l|l|}
\hline $\begin{array}{l}\text { Sample } \\
\text { identity }\end{array}$ & Fe & $\mathrm{Mn}$ & $\mathrm{Cu}$ & $\mathrm{Zn}$ & $\mathrm{Pb}$ & $\mathrm{Cd}$ & $\mathrm{Ni}$ & $\mathrm{V}$ & $\mathrm{Cr}$ & $\mathrm{THC}$ \\
\hline & \multicolumn{9}{|c|}{$\mathrm{mg} / \mathrm{kg}$} \\
\hline Ikpoba- Okha & 1527.6 & 11.23 & 3.22 & 22.21 & 0.09 & 0.019 & 0.28 & $\mathrm{NA}$ & 9.41 & 23142 \\
Oredo & 1396.2 & 18.22 & 4.09 & 19.14 & 0.01 & 0.003 & 0.92 & $\mathrm{NA}$ & 6.09 & 1985.4 \\
Egor & 1653.1 & 12.51 & 2.92 & 28.23 & 0.38 & 0.092 & 1.28 & NA & 24.7 & 2098.7 \\
Ovia NE & 1124.5 & 11.28 & 5.13 & 11.35 & 0.02 & $\mathrm{NA}$ & 0.09 & $\mathrm{NA}$ & 6.87 & 1445.0 \\
\hline Control & 1002.2 & 5.29 & 1.13 & 16.12 & 1.32 & 0.042 & 0.02 & NA & -2.83 & 851.5 \\
\hline Mean & 1340.72 & 11.706 & 3.298 & 19.41 & 0.031 & 0.307 & 0.52 & NA & 9.98 & 1738.96 \\
\hline
\end{tabular}

Table 3: Compositions of bacteria and fungi found in the rhizosperic soil of Panicum maximum

\begin{tabular}{|l|l|l|l|l|l|l|}
\hline $\begin{array}{l}\text { Sample } \\
\text { identity }\end{array}$ & $\begin{array}{l}\text { Bacteria counts } \\
\left(\mathrm{x} 10^{6} \mathrm{cfu} / \mathrm{g}\right)\end{array}$ & $\begin{array}{l}\text { Hydrocarbon } \\
\text { degrading } \\
\text { Bacterial Counts } \\
\left(\mathrm{x} 10^{6} \mathrm{cfu} / \mathrm{g}\right)\end{array}$ & $\begin{array}{l}\text { Percentage } \\
\text { hydrocarbon } \\
\text { degrading } \\
\text { bacteria }(\%)\end{array}$ & $\begin{array}{l}\text { Fungal counts } \\
\left(\mathrm{x} 10^{6} \mathrm{cfu} / \mathrm{g}\right)\end{array}$ & $\begin{array}{l}\text { Hydrocarbon } \\
\text { degrading } \\
\text { Fungal Counts } \\
\left(\mathrm{x} 10^{6} \mathrm{cfu} / \mathrm{g}\right)\end{array}$ & $\begin{array}{l}\text { Percentage } \\
\text { hydrocarbon } \\
\text { degrading } \\
\text { fungi }(\%)\end{array}$ \\
\hline Ikpoba- & 5.40 & 2.30 & 42.60 & 1.5 & 1.00 & 66.7 \\
Okha & 3.90 & 2.10 & 53.85 & 0.9 & 1.20 & 133.3 \\
Oredo & 4.90 & $2.10 \mathrm{~m}$ & 42.86 & 2.0 & 1.60 & 80 \\
Egor & 5.30 & 2.70 & 50.94 & 1.8 & 0.07 & 38.9 \\
Ovia NE & & & 7.69 & 2.2 & 0.07 & 31.82 \\
\hline Control & 0.39 & 0.03 & 7.67 & & \\
\hline
\end{tabular}


Table 4: Microorganisms isolated from rhizospheric soil

\begin{tabular}{|l|l|l|l|l|l|l|}
\hline & Microbial Isolates & Ikpoba-Okha & Oredo & Egor & Ovia NE & Control \\
\hline Bacteria & *Bacillus subtilis & + & & & & \\
& Micrococcus luteus & - & + & - & + & + \\
& Micrococcus varians & + & + & - & - & - \\
& *Pseudomonas putida & - & + & + & + & + \\
& Achromobacter sp & - & - & + & - & + \\
& *Bacillus pumilis & + & + & - & + & - \\
& Clostridium sp & + & - & - & - & + \\
& Serratia marascens & - & + & + & - & + \\
\hline Fungi & *Aspergillus flavus & + & - & + & + & + \\
& *Aspergillus niger & + & - & - & - & + \\
& Fusarium solani & + & + & + & + & + \\
& *Penicillium sp & - & - & + & + & + \\
& Geotrichum sp & - & + & - & - & - \\
& Rhizopus sp & + & - & - & + & + \\
& Trichoderma sp & - & - & + & - & - \\
\hline
\end{tabular}

*Hydrocarbon degraders, + present, - absent

This study thus provides information on the heavy metal content and microbial compostion of rhizophere of Panicum maximum in some auto mechanic workshop in Benin City. Evidence has been shown that the chemical conditions of the rhizosphere differ from those of the bulk soil, as a consequence of various processes that are induced by plant roots and/or by the rhizobacteria (Hinsinger, 2001; Jing et al., 2007). Plant-bacteria interactions could stimulate the production of compounds that could alter soil chemical properties in rhziosphere and enhance heavy metals accumulation in plants.

Soil microbes play significant roles in recycling of plant nutrients, maintenance of soil structure, detoxification of noxious chemicals, and control of plant pests and plant growth (Elsgaard et al., 2001; Filip, 2002). In this study, microorganisms isolated from the soil samples include eight (8) bacteria which are Bacillus substilis, Micrococcus luteus, Clostridium sp., Micrococcus varians, Pseudomonas putida, Achromobacter sp., Bacillus pumilis, Serratia marascens and seven (7) fungal species which include Aspergillus niger, A. flavus, Rhizopus sp., Penicillium sp., Geotrichum sp., Trichoderma sp., Fusarium solani.

The most prevalent microorganisms in soil within auto mechanic workshop in the four Local Government Areas are Micrococcus varians for bacteria while Aspergillus niger representing fungi. Microorganisms were more prevalent in soil samples around the auto mechanic workshop; this may be because, lesser oil pollution and heavy metals were present in the soil samples from the area compared to soil within the auto mechanic workshop in all the four Local Government Areas.
These microorganisms may have been involved in the remediation process, considering the fact that their prevalence, even in higher concentrations of pollution, may signify tolerance to these pollutants.

These identified as active members ofbioremediation microbial consortia by Ekundayo and Obuekwe (1997); Yogambal and Karegoudar (1997); Remero et al. (2001); April et al. (2000). Irwin (1998) reported that if site assessments reveal that species of indigenous microorganisms are unable to degrade target contaminants, exogenous microorganisms with the required biochemical capabilities can be introduced to successfully degrade specific waste compounds. Bacteria in bioremediation are prolific. Certain bacteria belonging to the Bacillus and Pseudomonas species have these desirable characteristics: they consume organic waste thousands of times faster than the types of bacteria that are naturally present in the waste; they grow and reproduce easily, are non-pathogenic, and do not produce foul odours or gas (Efeovbokhan et al., 2012).

A number of factors contribute to heavy metal reduction in polluted soils, including soil physicochemistry as well as biological action, most importantly the activities of local resident plant species (Ikhajiagbe and Chijioke-Osuji, 2012). Cataldo and Wildung (1978) reported that one of the factors governing metal availability to plants in soils is the solubility of the metal associated with the solid phase, since in order for root uptake to occur, a soluble species must exist adjacent to the root membrane for some finite period. The rate of release and form of this soluble species will have a strong 
influence on the rate and extent of uptake and, perhaps, mobility and toxicity in the plant and consuming animals.

In this study, it was noticed that there were more heavy metals at mechanic workshop compared to the control. This is could be attributed to frequent discard of waste engine oil (WEO) and petroleum by automobile engineers. These WEO and petroleum have been reported to contain relatively large amounts of hydrocarbons, including the highly toxic polycyclic aromatic hydrocarbon (PAH) (Wang et al., 2000) and toxic heavy metals (Edeberi and Nwanokwale, 1981). Panicum maximum found within and around these auto mechanic workshops tends to accumulate heavy metals due to its presence in areas waste engine soil. (Ikhajiagbe et al., 2014). Heavy metals present in the soil samples collected from the automechanics include chromium, lead, manganese, copper, nickel, vanadium, zinc, iron and cadmium. It is not clear exactly what levels of heavy metals in soil are safe or unsafe but microbes has proven to be effective in the bioremediation of these heavy metal so as to enhance crops/plant growth (Robinson et al., 2001; Turgut, 2003). Whisman et al. (1974) observed that most heavy metals like V, Pb, $\mathrm{Ni}$ and $\mathrm{Fe}$ that are below detection in unused lubricants oil gave high concentration values in used oil. However, after exposure of soil to experimental conditions and treatments, some of these heavy metals were below detectable limit.

According to Rasaq et al. (2015), Panicum maximum accumulated more of iron, zinc, copper, and less of lead and cadmium and very less of nickel and chromium. It is also noteworthy to know that in most site, the metals studied accumulated most in leaves, followed by root and then stem of the plant which may be an indication that the plants bioaccumulate metals more in the leaves which when consumed for a reasonable length of time by herbivores may accumulate in their body thereby increasing the chances of exposure of humans who is at the end of the food chain.

Conclusion: The persistence of the test plant in the oil-polluted auto mechanic workshop is an indication of adaptation to the stress imposed by the oil in soil. in spite of the metal composition within the rhizosphere, it was observed that a number of microorganisms exist. This may therefore suggest a favourable environment for the microorganisms within the root region of Panicum maximum.

\section{REFERENCES}

Adie, G. U. and Osibanjo, O. (2009). Assessment of soilpollution by slag from an automobile battery manufacturing plant in Nigeria African. Journal of Environmental Science and Technology 3(9): 239250 .

Anderson, T.A., Guthrie, E.A. and Walton, B.T. (1993). Bioremediation in the rhizosphere: Plant roots and associated microbes clean contaminated soil. Environmental Science and Technology 27:26302636.

Anoliefo, G. O., Ikhajiagbe, B., Okonofhua, B. O. and Diafe, F. V. (2006). Eco-taxonomic distribution of plant species around motor mechanic workshops in Asaba and Benin City, Nigeria: Identification of oil tolerant plant species. African Journal of Biotechnology 5 (19):1757-1762.

Anoliefo, G.O. and Edegbai, B.O. (2001). Effect of spent engine oil as a soil contaminant on the growth of two egg plant species, Solanum melongen $\mathrm{L}$ and $S$. incanum. J. Agric. Forestry and Fisheries 1:21-25.

April, T.M., Foght, J. M. and Currah, R.S. (2000). Hydrocarbon-degrading filamentous fungi isolated from flare pit soils in Northern and Western Canada. Canadian Journal of Microbiology 46(1): 38-49.

Cataldo, D.A. and Wildung, R.E. (1978). Soil and plant factors influencing the accumulation of heavy metals by plants. Environmental and Health Perspective, 27:149-159.

Edebiri, R.A.O. and Nwanokwale, E. (1981). Control of pollution from internal combustion engine used lubricant. Proceedings of the International Seminar Petroleum Industry and the Nigeria Environment. $12 \mathrm{p}$.

Efeovbokhan, V.E., Hymore, F.K. and Oyakhire, C.T.G. (2012). The Effects of Pseudomonas aeroginosa and Aspergillus niger on the Bioremediation of Raw and Treated Crude Oil Polluted Water. International Journal of Science and Technology 2(6): 2224-3577.

Ekundayo, E.O. and Obuekwe, C.A. (1997). Effects of oil spill on soil physicochemical properties of a spill site in a typic paledult of Midwestern Nigeria. Environmental Pollution 22: 187-196.

Elsgaard, L., Petersen, S.O. and Debosz, K. (2001). Effects and risk assessment of linear alkylbenzene sulfonates in agricultural soil. 1. Short-term effects on soil microbiology. Environmental Toxicology and Chemistry 20(8):1656-1663.

Fetzer, J.C. (2000). The chemistry and analysis of large polycyclic aromatic hydrocarbon. Wiley and Son Company, New York, United States of America. 843p. 
Filip, Z. (2002). International approach to assessing soil quality by ecologically-related biological parameters. Agricultural Ecosystem and Environment 88(2):689712.

Gerhardta, K.E., Huang, X. D.,Glicka, B .R., and Greenberg, B.M. (2009) Phytoremediation and rhizoremediation of organic soil contaminants: Potential and challenges. Plant Science 176:20-30.

Hinsinger, P. (2001). Bioavailability of soil inorganic P in the rhizospere as affected by root-induced chemical changes: a review. Plant Soil 237(2):173-195.

Ikhajiagbe B and Chinenye C. Chijioke-Osuji (2012). Heavy metal contents and microbial composition of the rhizosphere of Eleusine indica within an automechanic workshop in Benin City, Nigeria. Journal of the Ghana Science Association 14(2): 45 - 55.

Ikhajiagbe, B. and Anoliefo, G.O. (2011). Natural attenuation of a 14-month-old spent engine oil polluted soil. Journal of Soil Science and Environmental Management 2 (7): 184-192.

Ikhajiagbe, B., Chijioke-Osuji, C., Obonodi N. and Osaruese, U. (2014). Effects of soil amendments on the intrinsic qualities and development of soil seed bank of a monitored naturally attenuated petroleum hydrocarbon-polluted soil. 4(2): 59-71.

Irwin, P (1996). To clean up environmental spill, know your medium. Electrical World 8:37-40.

Jing, Y., He, Z. and Yang, X. (2007). Role of soil rhizobacteria in phytoremediation of heavy metal contaminated soils. Journal of Zhejiang University Science B 8(3): 192-207.

Meinz, V. (1991).Used oil characterization study. Washington state department of ecology ,solid and harzadous waste programme. Harzadous waste section Olympia, Washington. pp $504-511$.

Mohsen, S., Samira, A. and Mohammad, A.H. (2011). Enhancing Phytoremediation Efficiency in Response to Environmental Pollution Stress. InTech Publishers, Rijeka, Croatia. 284p.

Odjegba, V. andSadiq, A.O. (2002). Effects of spent engine oil on the growth parameters, chlorophyll and protein levels of Amaranthus hybridus L. The Environmentalist 22: 23-28.
Rasaq, A. O., Gregory, O. A., Olumayowa, J. O., Oladipo A. L. and Owolabi, M. S. (2015). Concentration of Heavy Metals in Root, Stem and Leaves of Acalypha indica and Panicum maximum Jacq from Three Major Dumpsites in Ibadan Metropolis, South West Nigeria. American Journal of Chemistry. 5(1): 40-48.

Romero, M.C., Hammer, E., Cazau, M.C. and Arambarri, A.M. (2001). Selection of autochthonous yeast strains able to degrade biphenyl. World Journal of Microbiology and Biotechnology 17: 591-594.

Schwab, A. P. and Banks, M.K. (1994) Biologically mediated dissipation of polyaromatic hydrocarbons in the root zone. In: Bioremediation Through Rhizosphere Technology. T. A. Anderson and J. R. Coats, eds. American Chemical Society, Washington DC, United States of America. pp. 132-141.

Turgut, C. (2003). The contamination with organochlorine pesticides and heavy metals in surface water in Küçük Menderes River in Rurkey,. Environment International 29:29-32.

Vwioko, D.E. and Fashemi, D.S. (2005). Growth response ofRicinuscommunisL. (Castor oil) in spent lubricating oil polluted soil. Journal of Applied Science and Environmental Management 9(2): 73 - 79.

Wang, Z. D., Fingas, M., Blenkinsopp, S., Sergy, G., Landriault, M., Sigouin, L., Lambert, P., (2008). Study of 25 year old Nipis Oil Spill: persistence of oil residues and comparisons between surface and subsurface sediments. Environmental Science and Technology 32:2222-2232.

Wei, S., Zhou, Q. and Wang, X. (2005). Identification of weed plants excludingthe uptake of heavy metals. Environment International 31:829-834.

Whisman, M.L., Goetzinger, J.W. and Cotton, F.O. (1974). Waste lubricating oil research. An Investigation of Several Re-fining Methods. Energy Research Center, Bureau of mines, Bartlesville.

Yogambal, R.K. and Karegoudar, T.B. (1997). Metabolism of polycyclic aromatic hydrocarbons by Aspergillus niger. Indian Journal of Experimental Biology 35: 1021-1023. 